\title{
Distinguishing Between the Capital Tax View and the Benefit View of the Property Tax at the Local Level
}

\author{
Russell R. Evans \\ Oklahoma City University • Oklahoma City, Oklahoma \\ Mary N. Gade \\ Oklahoma State University • Oklahoma City, Oklahoma
}

\section{Abstract}

The Great Recession of 2008 exposed municipalities across the U.S. to the dangers of over-reliance on a volatile sales tax base for general revenue financing. A 2010 interim study convened by the Oklahoma Legislature examined the possibility of offering access to the property tax base as a source of municipal general revenue. The feasibility of such a move depends crucially on understanding the economic incidence of the local property tax. Current research is divided on the issue, with one school proposing the property tax as a tax on capital generally (the capital tax view) and the other asserting the property tax as a user-fee for locally provided public services (the benefit view). We examine the incidence of the local property tax in Oklahoma County recognizing explicitly that the tax levy is really an aggregate of independent levies - each tied to the provision of a specific subset of local services - and that incidence outcome may vary by jurisdiction. An analysis of the 19 independent school districts in Oklahoma County over a 10-year period finds evidence that the incidence of the property tax varies both by levy and jurisdiction.

\section{Introduction}

Property taxes persist as a staple of local government finance. Wallis (2001) notes that while the role of the property tax at the national and state level has diminished over time, it continues to be the most important source of local government revenue. In fiscal year 2007, local governments in the U.S collected $\$ 518.6$ billion with just over $71 \%$, or $\$ 370.4$ billion collected via local property taxes. ${ }^{1}$ In the same period, local governments in Oklahoma collected $\$ 3.6$ billion, with property taxes accounting for roughly $52 \%$, or $\$ 1.9$ billion of total collections. In Oklahoma, county governments rely heavily on the property tax as a source of local revenue while municipalities rely instead on a general sales tax; school districts employ the property tax exclusively as a source of local funding. A 2010 Oklahoma legislative task force was convened to examine the feasibility of allowing municipalities access to the local property tax base as a source of general revenue funds. Interest in the 
property tax as a source of general revenue funding underscores the importance of understanding the incidence and efficiency implications of the local property tax. The unfortunate reality of an absent consensus is discussed subsequently.

Almost as widespread as the reliance on the property tax as a local revenue source is the dislike for and confusion surrounding the levy. O'Sullivan, Sexton, and Sheffrin (1995) document the fascinating passage of California's proposition 13 and the subsequent spread of property tax reform. In fact, while Wallis (2001) posits that the reliance of local governments on the property tax likely reflects the "ability to more closely match the beneficiaries of government investments, policies, and programs with the taxpayers who foot the bill," economic development packages often center on local property tax abatement programs (Dalehite, Mikesell, \& Zorn, 2005). Accompanying (and perhaps contributing to) a widespread distaste for the property tax, is a lack of agreement of its economic incidence. ${ }^{2}$

\section{Alternative Views of Property Tax Incidence}

The traditional view approaches the property tax as an excise tax levied on land and capital improvements. Generally considered in a partial equilibrium, single jurisdiction framework, the traditional view concludes that a jurisdiction's perfectly inelastic supply of land cannot escape its portion of the tax. The levy on land is borne by landowners and to the extent that land ownership increases with income, the property tax on land will be progressive. The excise tax on capital improvements begins with the assumption of perfectly elastic capital (between industries within a jurisdiction) and concludes that capital avoids the tax generally, leaving the burden with occupants (tenants) of the improvements. Depending on the measure of income employed, the excise tax on improvements was thought to be regressive to proportional. Carroll and Yinger (1994) test the hypothesis that the excise tax on improvements is fully shifted to tenants by investigating the rental housing market and conclude that, even under conditions of relatively elastic supply, landlords bear on average $\$ 0.89$ of every dollar of the tax, suggesting a much less regressive outcome than initially believed.

Adopting a Harberger (1962) general equilibrium framework, Mieszkowski (1972) proposes new view of the property tax. The new view positions the property tax as a general tax on capital (and is not so new anymore). The new view is now commonly referred to as the "capital tax view". The capital tax view recognizes explicitly that property is taxed economy wide, albeit at different rates. Therefore, regardless of the mobility of capital, it cannot escape the tax entirely. The portion of 
capital subject to the average rate of property taxation is defined as a "profits tax", falling on capital generally and progressively. Capital mobility will lead to capital migration into (and out of) relatively low (high) jurisdictions. These individual "excise tax" effects tend to offset each other, leaving the property tax as a progressive tax on capital. It is important to stress not only the progressive nature of the capital tax view, but also the distortionary impacts of the property tax under this view. Specifically, the property tax distorts capital use both between sectors and across jurisdictions, incentivizes governments to provide inefficiently low levels of public services, and gives rise to inter-jurisdictional redistribution of income. For a more exhaustive review of the historical development, extensions, and empirical studies of the capital tax view, see Zodrow (2001).

Building on the seminal work of Tiebout (1956), a model of the property tax as an efficient user fee for public services is articulated by Hamilton (1975) and extended convincingly be Fischel (1992, 2001). Under the "benefit view", individuals sort according to their demand for local services and then implement strict zoning requirements effectively limiting the ability of a low home value resident to consume public services at a discount. Extensions admit jurisdictions of heterogeneous home values (but similar demand for public services), and find fiscal differentials capitalized into home values, restoring the user fee aspect of the tax. ${ }^{3}$ Extending the argument to jurisdictions as municipal corporations and homeowners as rational maximizers of their share value, the "benefit view" envisions home owners rationally evaluating policy and zoning proposals, approving those that increase the value of their home and rejecting those that do not. Under the benefit view, the local property tax is an efficient user fee for local services, with no distortionary effect on the allocation of capital or distribution of income.

Zodrow (2008) observes that the "effects of the property tax, including its economic incidence, efficiency properties and distributional implications have been the subject of a long and contentious debate." ${ }^{4}$ While the debate is certainly entertaining, its resolution has significant applied implications. Indeed, Zodrow offers the comment above in the context of assessing the efficacy of shifts in the relative mix of state and local financing from local property taxes to alternatives administered at higher levels of governance. Clearly, this type of inspection requires some conclusion be reached as to property tax incidence. 


\section{Distinguishing Between Incidence Views: Issues and Considerations}

Empirical work on property tax incidence has largely centered on estimates of home price capitalization of fiscal differentials. Unfortunately, while fiscal capitalization is required to support the benefit view (given heterogeneous neighborhoods), its presence is not precluded by the "capital tax" view. Other work has focused on the anecdotal evidence of increased reliance on zoning, household participation in the zoning and expenditure process, and determinants of household location, all of which coincide with the behavioral assumptions of the benefit view without providing empirically testable hypotheses.

The first issue to arise is isolating an appropriate definition of the problem. Nechyba (2001) offers perspective on this issue by noting that there may not be one right model. Some jurisdictions may be characterized by the assumptions underlying the benefit view and others by those supporting the capital tax view. In other words, the problem defined as identifying the correct model universally may be misconstrued. Rather, a more correct statement of the research task may be in identifying the better model for a particular jurisdiction.

Second, the jurisdiction must be defined. Isolating effective tax rates for a large metropolitan area obscures the reality that the area is comprised of multiple counties, many cities, and dozens of school districts, all combined with special districts and parceled up into potentially hundreds of individual tax districts. We argue that it is at the individual tax district level where the assumptions of the opposing models will be most clearly delineated and offer the greatest success in empirically distinguishing benefit view jurisdictions from capital tax view jurisdictions.

Third, the property tax must be defined. The generically referenced property tax is really an aggregate levy: county rate, city rate, school district rate, higher education rate, fire district rate, etc. Even within each levy we find multiple delineations. Consider, for example, the adjacent jurisdictions with identical county and school district levies, but with different city and special district levies. It is possible that property tax incidence varies not only between jurisdictions, but between levies within a jurisdiction.

Fourth, an estimation procedure must be set forth that recognizes the expected population heterogeneity. Recent advances in computing power now make mixed models and their non-parametric cousins, latent class models, readily available. Of particular interest are models that estimate class membership, where class is defined according to property incidence. Such models have traditionally been more common 
in biostatistics; however, they are becoming more visible in the economic literature. Sjoquist, Walker, and Wallace (2005) employ a mixture model analysis to estimate differential responses to local fiscal conditions. It is quite possible that the failure to model population heterogeneity explicitly explains much of the difficulty in establishing firm and broad empirical support.

Finally, one other issue merits consideration. The municipal corporation narrative is complicated by the reality that zoning decisions are made at a level of government above the individual tax jurisdictions. Even if we retain the home price maximization objective, city and planning officials are functionally managers of a multi-product firm, overseeing home prices in many distinct tax jurisdictions. Just as managers engage in global profit maximization, so to we might expect city leaders to engage in optimal decisions for the community at large, even if to the detriment of individual jurisdictions. In other words, even active use of zoning regulations need not imply the assumptions required to support the benefit view are present in all tax districts.

\section{Analysis of Oklahoma County}

independent school districts, 8 special districts, and had a total assessed valuation of $\$ 5.34$ billion. In addition county collections, property tax levies serves as the primary source of funding for K-12 education as well as the state department of career and technology education. City governments primarily rely on sales tax revenue for funding, but a few do make use of a modest property tax levy. Ideally, one would use the individual tax districts as the unit of observation, but estimation of taxable value of property per district is ongoing. However, using the school districts as the unit of observation and investigating property tax base responsiveness to differentials in the school levy is sufficient to highlight some of the considerations addressed previously. Table 1 below summarizes some of the information available for each district. 
Table 1

Oklahoma County School Districts: Selected Characteristics

\begin{tabular}{crccc}
\hline $\begin{array}{c}\text { School District, } \\
2008\end{array}$ & Total Valuation & $\begin{array}{c}\text { Total Valuation } \% \\
\text { of County Total }\end{array}$ & $\begin{array}{c}\text { Facilities } \\
\text { OKC }\end{array}$ & $\begin{array}{c}\text { API, State } \\
\text { Total = 1279 }\end{array}$ \\
\hline Edmond & $\$ 1,246,215,690$ & $34.06 \%$ & $\mathrm{~K}-12$ & 1074 \\
Putnam City & $\$ 885,707,748$ & $22.81 \%$ & $\mathrm{~K}-12$ & 1449 \\
Mid-Del & $\$ 438,591,008$ & $16.81 \%$ & $\mathrm{~K}-12$ & 1281 \\
Western Heights & $\$ 227,324,271$ & $8.49 \%$ & $\mathrm{~K}-12$ & 1302 \\
Choctaw & $\$ 163,380,118$ & $3.94 \%$ & $\mathrm{~K}-12$ & 1090 \\
Deer Creek & $\$ 166,037,364$ & $2.97 \%$ & $\mathrm{~K}-12$ & 1312 \\
Luther & $\$ 72,024,124$ & $2.78 \%$ & $\mathrm{~K}-12$ & 1488 \\
Moore & $\$ 70,822,973$ & $1.67 \%$ & $\mathrm{~K}-12$ & 1230 \\
Harrah & $\$ 62,468,979$ & $1.33 \%$ & $\mathrm{~K}-12$ & 1385 \\
Oakdale & $\$ 58,983,612$ & $1.19 \%$ & $\mathrm{~K}-12$ & 1310 \\
Millwood & $\$ 34,717,695$ & $0.94 \%$ & $\mathrm{~K}-8$ & 1470 \\
Crooked Oak & $\$ 38,371,130$ & $0.68 \%$ & $\mathrm{~K}-12$ & 945 \\
Jones & $\$ 30,195,265$ & $0.67 \%$ & $\mathrm{~K}-12$ & 1018 \\
Piedmont & $\$ 24,097,402$ & $0.52 \%$ & $\mathrm{~K}-12$ & 1259 \\
Bethany & $\$ 12,745,824$ & $0.43 \%$ & $\mathrm{~K}-12$ & 1416 \\
Crutcho & $\$ 10,667,830$ & $0.24 \%$ & $\mathrm{~K}-12$ & 1422 \\
Mustang & $\$ 7,327,802$ & $0.22 \%$ & $\mathrm{~K}-8$ & 641 \\
Mcloud & $\$ 6,365,510$ & $0.12 \%$ & $\mathrm{~K}-12$ & 1362 \\
\hline
\end{tabular}

The school districts with the largest tax base are Oklahoma City (OKC), Edmond, Putnam City, and Mid-Del. It is interesting to note that Edmond and Mid-Del are Oklahoma City suburbs to the north and east of the city respectively. Putnam City, by contrast, is well within the main development of the city. Crutcho and Oakdale are small districts serving kindergarten through eighth grade only, before feeding into adjacent high schools. The final column reports the Academic Performance Index, a standardized accountability test required through the No Child Left Behind legislation. In 2008, the state's score was 1279 , offering a comparison against the performance of the districts presented. 
Table 2

Model Variables, 2008

\begin{tabular}{|c|c|c|c|c|c|c|}
\hline $\begin{array}{l}\text { School District, } \\
2008\end{array}$ & Net Valuation & $\begin{array}{c}\text { County } \\
\text { Rate }\end{array}$ & $\begin{array}{c}\text { School } \\
\text { District } \\
\text { Rate }\end{array}$ & $\begin{array}{c}\text { Career } \\
\text { Tech } \\
\text { Rate }\end{array}$ & $\begin{array}{c}\text { Diff. } \\
\text { from Avg. } \\
\text { School } \\
\text { District } \\
\text { Rate }\end{array}$ & $\begin{array}{c}\text { Diff. } \\
\text { from Avg. } \\
\text { Career } \\
\text { Tech } \\
\text { District } \\
\text { Rate }\end{array}$ \\
\hline OKC & $\$ 1,734,580,222$ & 23.18 & 52.48 & 15.45 & $(9.48)$ & 1.45 \\
\hline Edmond & $\$ 1,220,056,252$ & 23.18 & 66.23 & 15.69 & 4.27 & 1.69 \\
\hline Putnam City & $\$ 858,874,911$ & 23.18 & 60.72 & 15.69 & $(1.24)$ & 1.69 \\
\hline Mid-Del & $\$ 418,631,144$ & 23.18 & 65.05 & 17.3 & 3.09 & 3.30 \\
\hline Western Heights & $\$ 225,014,196$ & 23.18 & 57.92 & 5.08 & (4.04) & (8.92) \\
\hline Deer Creek & $\$ 163,046,388$ & 23.18 & 76.08 & 15.69 & 14.12 & 1.69 \\
\hline Choctaw & $\$ 154,261,735$ & 23.18 & 66.66 & 16.24 & 4.70 & 2.24 \\
\hline Luther & $\$ 70,886,600$ & 23.18 & 56.19 & 16.24 & $(5.77)$ & 2.24 \\
\hline Moore & $\$ 67,960,941$ & 23.18 & 67.41 & 5.08 & 5.45 & (8.92) \\
\hline Harrah & $\$ 60,024,314$ & 23.18 & 57.6 & 16.24 & $(4.36)$ & 2.24 \\
\hline Oakdale & $\$ 58,478,251$ & 23.18 & 59.52 & 0 & $(2.44)$ & $(14.00)$ \\
\hline Crooked Oak & $\$ 38,035,196$ & 23.18 & 57.90 & 15.45 & $(4.06)$ & 1.45 \\
\hline Millwood & $\$ 33,607,078$ & 23.18 & 59.55 & 15.69 & $(2.41)$ & 1.69 \\
\hline Jones & $\$ 28,637,254$ & 23.18 & 64.3 & 16.24 & 2.34 & 2.24 \\
\hline Piedmont & $\$ 23,248,353$ & 23.18 & 74.51 & 15.72 & 12.55 & 1.72 \\
\hline Bethany & $\$ 12,227,320$ & 23.18 & 67.58 & 15.72 & 5.62 & 1.72 \\
\hline Crutcho & $\$ 10,420,521$ & 23.18 & 48.18 & 17.3 & (13.78) & 3.30 \\
\hline Mustang & $\$ 7,024,802$ & 23.18 & 68.42 & 15.72 & 6.46 & 1.72 \\
\hline McLoud & $\$ 6,016,827$ & 23.18 & 50.93 & 15.47 & (11.03) & 1.47 \\
\hline
\end{tabular}

As data collection continues, we assess the need to treat individual districts as heterogeneous subjects by investigating the relationship between a district's property tax base and its relative school district levy. Our approach is similar in spirit, though more narrow and less complex, to that of Wassmer (1993). We begin by collecting data on the 19 districts for the period 1981 to 2008. We use the net valuation of property as a measure of the property tax base within each jurisdiction. Then, creating the average levy for both school district and CareerTech for every time period, we construct a local tax differential. An overview of the data for 2008 is provided in Table 2. Note that the data reflect a 2008 average school district levy of 61.96 mills and average CareerTech levy of 14.00 mills. Similarly, table 2 indicates that the 
OKC school district imposed a 2008 levy that was 9.48 mills below the average and a CareerTech levy 1.45 mills above the average.

Now consider the alternative positions. The capital tax view would have us believe that high tax jurisdictions will be characterized by capital outflow (ceteris paribus) as capital, (and people), move to neighboring jurisdictions offering similar levels of services with lower property tax collections. The benefit view counters with Fischel (2001) saying, "Voters are pleased that their home values rise if schools and bicycle paths are improved (even if they don't have children or ride bicycles), but are displeased by the reduction in their home values from increased local taxes. If the appreciation effect exceeds the depreciation effect, they approve the decision..." Note that it is only at the margin under the benefit view that increases in property tax rates yield no change in the property tax base. Indeed, under the assumptions of the model and the logic of the municipal corporation, a jurisdiction might be expected to enjoy an extended period of asset appreciation as the municipal directors strategically pursue the most profitable proposals first. Suffice it to say, we expect relatively high tax jurisdictions to have a negative effect on property tax base under the capital tax view and a zero to positive effect under the benefit view.

\section{The Model}

The model is fitted using a simple semi-log specification, where coefficient estimates are interpreted as semielasticities. Specifically, the model is,

$$
\ln (N E T V A L)=\beta_{0}+\beta_{1}^{*} Y E A R+\beta_{2} * D A S D R T+\beta_{3}^{*} D A C T E C H R T+\varepsilon
$$

We exclude Oakdale and Crutcho from the analysis, leaving the remaining 17 districts who serve K-12 needs. The results are presented as Model 1 below. The results suggest that all variables are statistically significant, though DACTECHRT only marginally so. The YEAR coefficient is interpreted as the expected percent change in NETVAL over a one-year period. That is, holding all other influences constant, the property tax base in the city seems to be growing at an average annual rate of 5.6\%. Likewise, every one unit change in DASDRT and DACTECHRT are expected to exert a downward influence of $3.5 \%$ and $4.7 \%$ on property tax base respectively. 


\section{Model 1 = All Districts}

$\ln (N E T V A L)=16.57093+0.056193$ YEAR -0.035413 DASDRT -0.047853 DACTECHRT

$t=(95.544)$

$(-3.469)$

$$
0.091023 \quad F \text { - statistic }=15.75505
$$

While we are pleased generally with the reasonableness of the coefficients, our intent at this stage is only to look for evidence that not all jurisdictions within the county are similarly classified according to tax incidence. A more rigorous econometric specification will follow.

To explore further, we divide the individual school districts into groups based on their location relative to the city center. These categories are simply city (school district encompassed by OKC proper), suburb (school district shares a border with the city), and rural (school district does not share a border with the city). We reestimate the model for our city, suburb, and rural districts individually and present the results below. Again, in all models all variables are statistically significant, with one only marginally significant and so indicated with an (*). All coefficients have an analogous interpretation to those presented in the original model.

\section{Model 2 = City Districts}

$\ln (N E T V A L)=17.87536+0.032997$ YEAR $-0.114850 D A S D R T-0.062425 D A C T E C H R T$

$$
t=(78.616)
$$

$$
r^{2}=0.377885 \quad F-\text { statistic }=27.536
$$

The results when looking at a subset of the panel consisting of districts located entirely within the city suggest the capital view is associated with the school district levy while the benefit view explains the career tech levy. This outcome is perhaps not surprising. School districts in the heart of the Oklahoma City metro area are among those with the highest levies (and therefore above average school district rates, DASDRT $>0$ ) but the product provided to homeowners apparently is not sufficient to increase home values enough to offset the discount created by the present value of future tax payments. In contrast, in the central city the career tech system can provide valuable vocational training, jobs assistance, small business guidance, 
and other programs that are expected to be of value to local residents. In this case, proximity to a well-funded and peak functioning career tech campus appears to be reflected in home values.

\section{Model 3 = Rural Districts}

$$
\begin{gathered}
\ln (\text { NETVAL })=14.55768+0.075004 \text { YEAR }-0.030661 D A S D R T-0.339869 D A C T E C H R T \\
t=(66.478) \\
r^{2}=0.412901 \quad \text { (6.775) }
\end{gathered}
$$

When restricting the panel to look at the subset of rural school districts (districts within the county that do not share a border with the main section of the city), coefficients change signs and suggest a different reality. In rural districts, both the school district levy and the career tech levy seem to indicate a benefit view reality. While the influence of the school district levy is modest, it nonetheless suggests that capital flows into these districts in response to the value that is provided through local education funded through rates below the regional average. The stronger impact, however, is associated with the CareerTech levy. This is also not surprising as the career tech system is home to a vital collection of agricultural support programs including Agricultural Education, Agricultural Business Management, and Future Farmers of America among others. Proximity to this vital support system serves as a benefit to local residents with positive implications for local home values.

\section{Model 5 = Suburb Districts}

$$
\begin{aligned}
& \ln (N E T V A L)=15.83206+0.067263 \text { YEAR }-0.052584 D A S D R T-0.074372 D A C T E C H R T \\
& t=(57.348) \\
& (-1.767)^{*} \\
& r^{2}=0.130938 \quad F-\text { statistic }=9.642632
\end{aligned}
$$

Finally, the pooled sample is restricted to a subset of districts representing the Oklahoma City suburb areas. These districts are all removed from the central city but share at least one border with the city. Again, an interesting and somewhat intuitive pattern emerges from the estimated coefficients. The school district levy 
supports a strong benefit view conclusion suggesting capital flows into suburban districts in response to the value provided by suburban school districts driving up home values. In contrast, while the career tech system offers a host of continuing education courses that might be of interest to suburban residents (photography, culinary, basics of investing, etc.) it appears these programs are not sufficient to counter the negative impact associated with the tax levy and exert negative pressures on home prices.

The preceding discussion suggests two important contributions. First, there is evidence that the incidence of the property varies by jurisdiction, suggesting the presence of both capital view and benefit view jurisdictions. Pooled samples result in misleading estimates as the sample likely includes observations of distinct subsets that may or may not be distinguished by observable characteristics. An extension of this paper would involve estimation of models that explicitly account for the underlying population heterogeneity.

Second, the property tax is really an aggregate levy with the individual levies each exhibiting distinct incidence implications. Future research should recognize the complex structure of the levy explicitly in developing appropriate incidence models.

\section{Discussion and Conclusion}

While the magnitudes of the coefficients are reasonable enough, it is the switching of the signs of the coefficients that is of most interest. For example, in all models the trend growth of property tax base is positive and significant, with the greatest trend growth being experienced in rural districts at $7.5 \%$ per year, followed by suburb districts at $6.7 \%$, and city center districts at $3.3 \%$. All of these estimates are consistent with current development patterns in Oklahoma County.

Looking and the differential impacts of school district tax rates, we find it to be strongly negative and significant in magnitude at the city level, but equally as strongly positive and significant in magnitude at the rural and suburb levels. The coefficients suggest a deeper look is merited into the possibility of capital tax view jurisdictions in the city and benefit view jurisdictions in the periphery. Again, this is consistent with relocation patterns throughout the county as homeowners essentially shop for school value. This is perhaps the strongest evidence in favor of the argument to investigate property tax incidence at the local level and expect population heterogeneity.

Finally, the differential impacts of the CareerTech levy also indicate a benefit view to this service in the city and rural areas, but not in the suburbs. These findings are consistent with the vocational and agricultural objectives of the CareerTech system. 
The ongoing property tax incidence debate is not only interesting academically but also has significant policy implications. Without a better understanding of the role the local property tax plays in regional efficiency and distribution outcomes, comparisons against alternative methods of local finance are near impossible. We have proposed some parameters to facilitate future empirical investigation, among them: an inherently local focus, a disaggregation of the property tax levy, and explicit incorporation of the possibility the incidence implications may vary across jurisdictions. We illustrate using easily accessible data and a straightforward model how significantly the interpretations can vary depending on the perspective taken. Ultimately, we find reason to expect differing incidence outcomes in Oklahoma County's city, suburb, and rural areas.

As tax reform discussions progress at the state and national level, the business community will be asked to lend their significant voice to the various alternatives. Crucial to a region's ability to foster economic development will be its success at designing efficient systems of local finance. The evidence we provide for Oklahoma County suggests the need for local examination of the incidence of the property tax on case-by-case basis.

\section{Notes}

1 Local government is given by county, municipality, township, special district, and school district

2 William Fischel (2001) opens a recent article with the following sentence: "The local property tax is so widely criticized by scholars and reformers that its persistence demands some explanation."

3 The fiscal differential is given by the difference in the present value of the benefits received and local property taxes paid.

4 For some additional perspective on the early contributions to the debate, see Aaron (1974) and Musgrave (1974).

\section{References}

Aaron, H. (1974). A New View of Property Tax Incidence, The American Economic Review, 64, 212-221.

Carroll, R. and Yinger, J. (1994). Is the Property Tax a Benefit Tax? The Case of Rental Housing, National Tax Journal, 47, 295-316. 
Dalehite, E.G., Mikesell, J.L., and Zorn, C.K. (2005). Variation in Property Tax Abatement Programs Among States. Economic Development Quarterly 19, 157.

Fischel, W.A. (1992). Property Taxation and the Tiebout Model: Evidence for the Benefit View From Voting and Zoning, Journal of Economic Literature, 30, 171-177.

Fischel, W.A. (2001). Municipal Corporations, Homeowners and the Benefit View of the Property Tax, in Property Taxation and Local Government Finance, ed. By W. E. Oates, Lincoln Institute of Land Policy, Cambridge, MA.

Hamilton, B. W. (1975). Zoning and Property Taxation in a System of Local Governments, Urban Studies, 12, 205-211.

Harberger, A.C. (1962). The Incidence of the Corporate Income Tax, Journal of Political Economy, 70, 215-240.

Mieszkowski, P. (1972). The Property Tax: An Excise Tax or a Profits Tax? Journal of Public Economics, 1(1), 73-96.

Nechyba, T. J. (2001). The Benefit View and the New View: Where do We Stand, Twenty-Five Years into the Debate? Property Taxation and Local Government Finance, ed. by W. E. Oates, Lincoln Institute of Land Policy, Cambridge, MA.

O’Sullivan, A., Sexton, T. A., and Sheffrin, S.M. (1995). Property Taxes and Tax Revolts: The Legacy of Proposition 13, New York and Cambridge, UK: Cambridge University Press.

Sjoquist, D.L., Walker, M.B., and Wallace, S. (2005). Estimating Differential Responses to Local Fiscal Conditions: A Mixture Model Analysis, Public Finance Review, 33, 36-61.

Tiebout, C. M., (1956) A Pure Theory of Local Expenditures, Journal of Political Economy, 64, 416-424.

Wallis, J. J. (2001). A History of the Property Tax in America, in Property Taxation and Local Government Finance, ed. By W. E. Oates, Lincoln Institute of Land Policy, Cambridge, MA.

Wassmer, R. (1993). Property Taxation, Property Base, and Property Value: An Empirical Test of the "New View", National Tax Journal, 46, 135-160.

Zodrow, G. R. (2001). Reflections on the New View and The Benefit View of the Property Tax, in Property Taxation and Local Government Finance, ed. By W. 
E. Oates, Lincoln Institute of Land Policy, Cambridge, MA.

Zodrow, G. R. (2008). The Property Tax Incidence Debate and the Mix of State and Local Finance of Local Public Expenditures, Oxford University Centre for Business Taxation, forthcoming, CESifo Economic Studies.

\section{Biographical Sketches of Authors}

Russell R. Evans, Ph.D. is the Executive Director of the Steven C. Agee Economic Research and Policy Institute in the Meinders School of Business at Oklahoma City University. Dr. Evans currently teaches courses in Applied Business Statistics and Public Finance, while working closely with local policymakers advising on such matters as revenue forecasts, economic development, and policy analysis.

Mary Gade, Ph.D. is an Associate Professor of Economics and the Graduate Coordinator in the Spears School of Business at Oklahoma State University. Dr. Gade teaches courses in Public Finance, Game Theory, and Sports Economics. Her research interests are centered on property taxes, and state and local government finance. 